\title{
Proposal to Implement Low Cost Digital Communication Using VoIP Technology, a Case Study
}

\author{
Hesmeralda Rojas, Ronald Renteria, Evelyn N. Luque, Marleny Peralta, and José L. Merma
}

\begin{abstract}
Many organizations still face the challenge of adopting digital technologies to achieve substantial competitive advantages in the commercial field and in terms of innovation. Which is the case of Public organizations in Peru since they do not have the same performance indices than private organizations, various studies situate public entities at a considerable disadvantage compared to private entities. This article presents a proposal for the implementation of low-cost digital communications using VoIP technology to improve communication with the costumer and increase the income collected by the Centre for the Provision of Services of Micaela Bastidas National University. VoIP technology enables the availability of global digital communications at low-cost in order to achieve operational excellence and compete for market share.

This article presents a proposal covering technical and management aspects for the implementation of the solution; this allows collaborative work with an integrated vision that enabled to have clear and fluid communication with members of the project. Surveys were carried out by the users who received the service and a monthly evaluation of income behavior was collected. The results obtained show a relationship between the use of VoIP technology, and the significant increase in income indices and better customer communication.
\end{abstract}

Index Terms-VoIP, continuous communication, meaningful communication, timely communication, user satisfaction.

\section{INTRODUCTION}

We are at the dawn of the Fourth Industrial Revolution, which represents a transition to a new set of digital technologies, despite this, many of the information and communication technologies are not accessible from the point of view of costs. According to the report given by the World Economic Forum [1], Peru is ranked in 90th out of 139 countries, with a mobile prepaid tariff of 0.32 \$ per minute on average; over Colombia, Chile, Mexico and the vast majority of European countries; the first position is for Hong Kong with an average rate of 0.02 \$ per minute. With regard to fixed internet tariffs, Peru is ranked 102th out of 139 countries with 51 \$ per month on average, while Vietnam ranks 1st with 2.59 \$ per month on average. These figures reflect that the cost of communication and an access in Peru, from the economic point of view, is far from being

Manuscript received June 21, 2018; revised August 1, 2018.

Hesmeralda Rojas, Evelyn N. Luque, Marleny Peralta, and José L. Merma are with Micaela Bastidas National University, Academic Professional School of Informatics and Systems Engineering, Abancay, Apurímac-Perú (e-mail: hrojas@unamba.edu.pe, evelyn_naida@hotmail.es, mperalta@unamba.edu.pe,jmerma@unamba.edu.pe).

Ronald Renteria is with Alas Peruanas University, Faculty of Business Sciences and Education, Abancay, Apurímac-Perú (e-mail: r_renteria@doc.uap.edu.pe). affordable.

Information and communication technologies have been inserted into various business models becoming an integral part and playing a determining role for their development. Companies that pass in a digital economy achieve a substantial competitive advantage in the commercial field, and innovation terms [1]. In this scenario, we must take full advantage of the benefits derived from emerging technologies that open further opportunities to produce competitive advantages. The TIC improve management, notably in the commercial and services sector.

\section{VoIP}

The digital revolution must ensure the availability of global digital communications with a low-cost processing. An alternative in this context is the VoIP (Voice over Internet Protocol), which is a technology that allows you to use the Internet broadband to make and receive voice and videophone calls [2]. VoIP allows you to take analog audio signals, which are emitted when we talk on the phone and transforms them into digital data. This transition from analog to digital data opens the door to the union of two historically separate worlds, voice and data transmission, therefore, VoIP instead of being a service it is a technology.

In studies like [3] the adoption of VoIP technology allows small businesses start with voice services without having to establish new networks or using their existing infrastructures. In addition, it offers economic advantages since they can be delivered together in an IP network, data and voice services, giving additional bandwidth use [4]. According to [5], VoIP telephony requires less infrastructure compared to cable circuit switching technology.

According to [6], by 2017 there will be 1 billion worldwide VoIP users; by 2018, only $6 \%$ of the United States citizens will use traditional landlines, the worldwide market of VoIP service will expand by $10 \%$ each year until 2021. In 2013, the regional distribution of VoIP subscribers was the following: East Asia covered $35.7 \%$ of the market share, Europe 32.9\%, North America 25.1\% and the rest of America 4.6\%. [7] this indicates that about $31 \%$ of companies use VoIP technology due to the fact that they increase productivity, cost savings and a competitive advantage over companies that use PSTN - Public Switched Telephone Network by reducing communication costs. In Peru, only $25 \%$ of telephone lines operate with VoIP which is seen primarily in the business sector [8].

The advantages of VoIP are many, in the study [9] are cited:

- Low cost: One of its main advantages is the use of existing infrastructure without additional wiring costs. 
- $\quad$ Service Integration: An integration with the traditional public telephone network is made (PSTN), which also provides audiovisual communication sessions on network packets.

- $\quad$ High scalability and facility of updating: VoIP system allows an increase in connectivity by increasing the data speed and functionality of the Internet. The hardware cost is very low as well, because it is based on hardware components to connect to the internet.

- $\quad$ Disaster recovery: Due to the failure can be monitored through various channels.

- Security: A Virtual Private Network (VPN) can be implem `ented to restrict access to internet bandwidth and use different protection methods by this way.

VoIP technology applied to improve communication in an organization can lead to an impact on the business environment [9] for this purpose, communication must be significant, timely and continuous [10] in order to achieve projected goals. Unified communication in companies with 100 employees can save considerable time of 191 hours per day, and \$ 920.00 per year in productivity [11]. At the same time, the research carried out by [12], explores the perspective of the internal communication effect and employee satisfaction, finding a positive effect on employee satisfaction and a significant influence on internal integration, which is reflected in the external integration of the company. Effective communication in cooperation with employee satisfaction is a requirement to improve the performance of the organization.

\section{SCOPE OF THE STUDY}

This article presents to Micaela Bastidas National University, Apurímac (UNAMBA) created in 2000. The University Law 30220 in its article 54. Production centers of goods and services, states: "Universities can build production centers of goods and services that are related to their specialties, academic areas or research works". UNAMBA has the support of the Internet and Information Center (IIC), which is a production center created with the purpose of providing education in the field of computing and information science, so as to the population can obtain computer skills that are essential for any profession or job. Likewise, the center offers a certification, which is valid in the recruitment process for personnel in order to increase the curriculum vitae or certify knowledge in certain subjects. The IIC offers various courses that are opened according to the amount of people pre - registered; pre-registration process is done through the website or at the center's head office. When the number of people pre-registered is at least fifteen, the course must begin; at this time that the schedule of activities is informed to the users. Previously, communication was made with the user through email. Statistic have shown that this way has not been effective. First of all, the report made by [13] indicates that in Peru, only $40.2 \%$ people have access to the Internet; in Apurímac, the percentage is $19.1 \%$. In addition to this reality, studies such as that of [14] considers that communication by electronic mail is not appropriate, due to its particular limitations such as not being able to transmit the tone of voice or cultural norms, according to [15] communication is poor when transmit emotion, and in this study, employees reported feeling less connected to their co-workers when using e-mail.

The ISO 9001 requires systems to communicate with the client in relation to related to the product information, in this case, information and starting dates regarding courses that are going to be opened. It is vital to have the certainty that the information is going to arrive to its destination and the product can be further promoted, in other words, the final user has the option to made questions, know the existing offer and find the best option for them; this way of working allows to promote and "sell" the product. In the research done by [16] the non-face-to-face attention is studied in which the customer service is given virtually with reduced costs in telephone calls compared to public switched telephone network (PSTN).

The IIC conducts its administrative procedures with limited financial resources in a market, for both internal and external communication, in which there is a competition with private companies for market share, in the research made by [17] public company presents itself at a disadvantage compared to private company, and adding to this there are budget constraints. For these reasons, a proposal for implementation of low-cost VoIP technology that seeks to improve the income levels collected and internal communication of the UNAMBA IIC is presented.

\section{PROPOSAL}

The proposal for implementing a low-cost service using VoIP technology is presented, which includes technical and management aspects which as a whole comprise a work with integrated vision. The proposed scheme is detailed below.

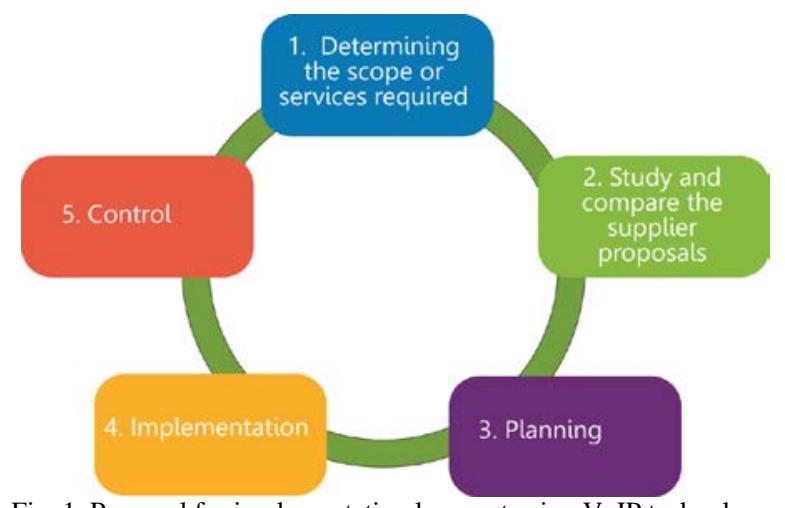

Fig. 1. Proposal for implementation low cost using VoIP technology.

\section{A. Determining the Scope or Services Required}

The services that are required for the type of project must be determined. Regarding VoIP, it can transport various types of information, for this study we worked with the voice component.

\section{B. Study and Compare the Supplier Proposals}

In the market there are wide range of vendor proposals. An important factor is to evaluate how the rates are offered. There are tariffs per minute: $60 / 60$, they have a certain price per minute, but it means that even if the user speaks only ten seconds every call will be considered as one minute; in compensation, this plan offers calls to fixed or private networks for free. The 30/30 tariff has the same mode of 
work, regardless of the duration of a call and it will be charged for thirty-second intervals. Finally, there is a plan per second that bills for each consumed. In this project we chose the plan second, despite of the fact that this plan does not have the advantages of free services such as the fixed telephony it was noted that the list of people pre-registered usually had a cell phone number as a contact number.

\section{Planning}

In this stage, roles and responsibilities of the project members were determined. The personnel of the area had to have their functions defined. A schedule of activities was established according to the availability of existing laboratories, and the estimated demand. This information was always available to all participants and work team.

A protocol was defined for the transmission of information to users at the time of telephone communication.

\section{Implementation}

\section{System requirements:}

- ATA: Analogue Telephone Adapter is a device that converts analog signals, such as voice, to digital or vice versa. It can be connected to traditional telephones and faxes. The ATA has an ethernet port, a port FXS and FXO port.

- $\quad$ FXS: Foreign Exchange Station, it is the interface of the VoIP device which can connect directly to phones, faxes analog line.

- FXO: Foreign Exchange Office, it allows you to connect directly to the PSTN network so that IP terminals make calls to terminals that do not have Internet access

- $\quad$ Codecs: they convert analog voice into IP packets so they can be sent over the network; finally, they decoded in voice in the receiving terminal. Codecs take samples of the audio signal thousands of times per second, then they are compressed and sent to be reconstructed. To join them again, some audio samples are lost, but the human ear does not perceive. The most employed Codecs are G711, G723.1, G718A and G729 [18].

- SIP protocol: Session Initiation Protocol, it is a standard developed by the IETF, enables the signaling to establish calls and conferences on IP networks. It is a control protocol or signaling-level session for the creation, modification and completion of multimedia sessions of one or more participants.

\section{E. Control}

The control was carried out by all the team involved in the execution of the project in an in-person meeting environment. The objective of the meetings was to show the status of the project, the risks detected, and possible modifications to be inserted.

A database of pre-registered and potential users, who had requested information about the courses, was created. The progress status of each user was registered using flags: Green - Confirmed: when the communication was made and the user finally signed up, Yellow - On hold: when the communication was made and the user confirmed his participation, but he has not yet registered and Red Pending: when communication has not been possible.

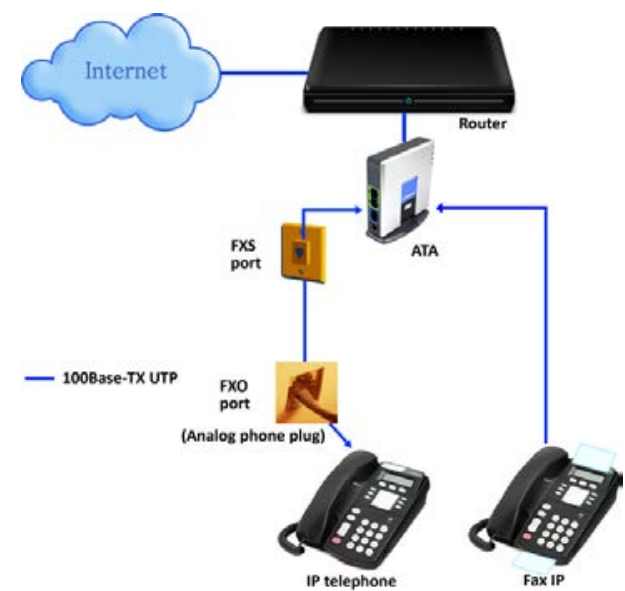

Fig. 2. Physical design of the VoIP solution.

\section{RESUlTS}

The results obtained after the implementation of the project were measured from the economic point of view by making a comparison between the incomes in 2015 and 2016; user perception and a financial assessment was made of the investment made in this technological infrastructure, calculating the Net Present Value and the Internal Rate of Return.

\section{A. Income Assessment}

The income collected from the services supply centers during the execution of the project was from December 2015 to June 2016, which is presented in Fig. 4.

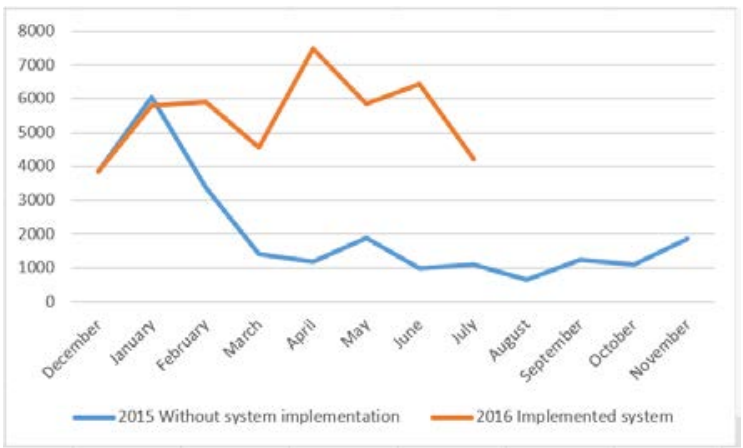

Fig. 3. Income collected at the Internet \& Information center - UNAMBA.

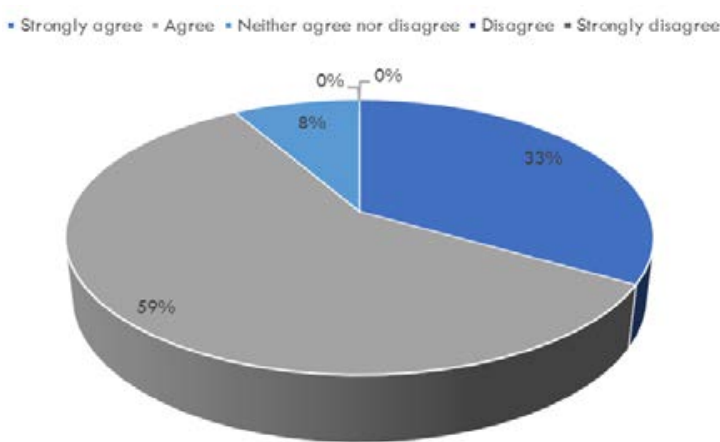

Fig. 4. Question 01: The communication by telephone to inform you about the starting date of courses and courses opened, was it done in a timely manner?

The incomes in 2015 and 2016, perceiving a notable increase between the management with VoIP technology implementation and the management without its implementation. 


\section{B. User Perception.}

On the other hand, the satisfaction level of the communication perceived by the users was measured through a survey.

It is observed that the information received about courses through telephone was largely perceived as timely by users CII.

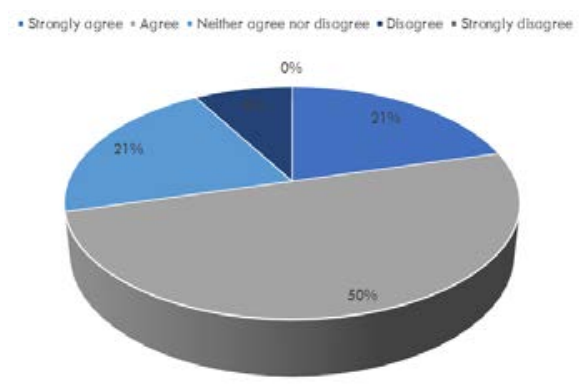

Fig. 5. Question 02: Do you consider that the information provided by telephone allowed you to know better what the organization does?

The information transmitted via phone is significantly (71\%) more effective to publicize the products and services offered by the IIC.

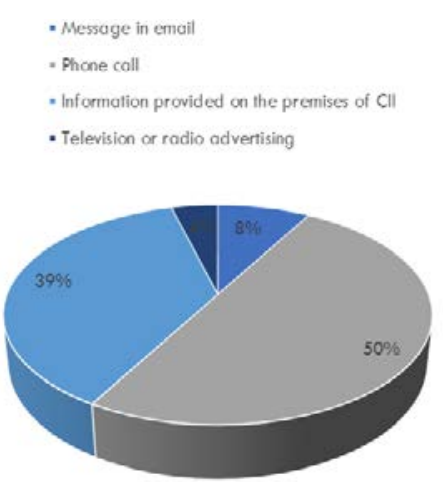

Fig. 6. Question 03: Which of these options that were sent to you do you consider that led you to make the decision to take a course in the IIC?

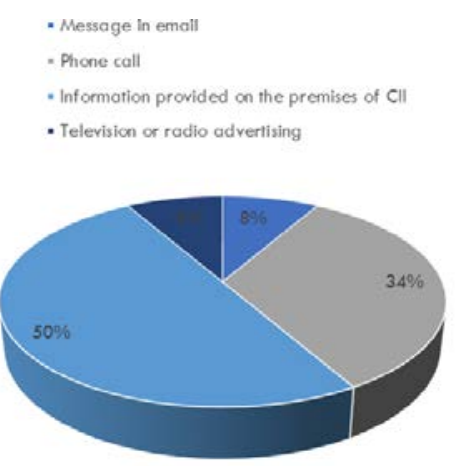

Fig. 7. Question 04: Which of the options received do you consider had more precise information on schedules, payment options and courses offered by IIC?

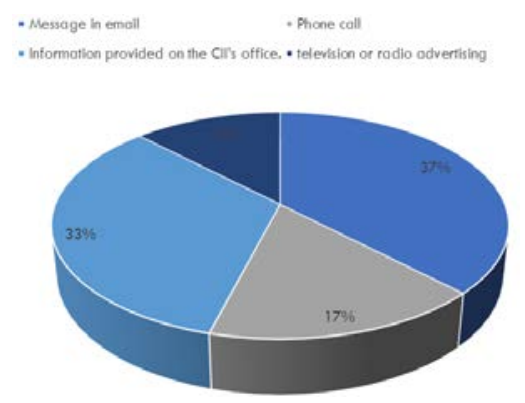

Fig. 8. Question 05: By which medium of communication would you like to be informed about new IIC's services?
It is observed that in $50 \%$ of the respondents, telephone communication influenced the decision to take a course in the IIC, while for $38 \%$ of the respondents were influenced by visit to the IIC's offices, and only in $8 \%$ and $4 \%$ were influenced by email and advertising respectively.

For subsequent communications on new IIC services, $37 \%$ of users prefer e-mail communication, then $33 \%$ of users prefer to visit CII's office, $17 \%$ prefer telephone communication and $13 \%$ radio or television advertising.

About the accuracy of the information, half of the users considered that they received more accurate information by visiting IIC's office, while $34 \%$ of users considered that accurate information was given by telephone.

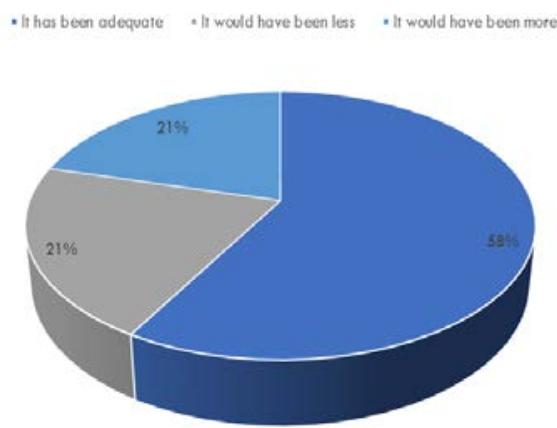

Fig. 9. Question 06: Do you consider that the periodicity of communication has been adequate?

TABLE I: ATTRIBUTE MEASUREMENT RESULTS: SIGNIFICANT

\begin{tabular}{|c|c|c|}
\hline \multicolumn{3}{|c|}{ COMMUNICATION } \\
\hline Question & Alternative & Percentage \\
\hline \multirow{5}{*}{$\begin{array}{l}\text { Question } 02 \\
\text { Do you consider that the } \\
\text { information provided by } \\
\text { telephone allowed you to know } \\
\text { better what the organization } \\
\text { does? (Products and services)? }\end{array}$} & Strongly agree & $20,83 \%$ \\
\hline & Agree & $50 \%$ \\
\hline & Disagree & $20,83 \%$ \\
\hline & Strongly Disagree & $8.33 \%$ \\
\hline & Don't know & 0 \\
\hline \multirow{4}{*}{$\begin{array}{l}\text { Question } 03 \\
\text { Which of these options that } \\
\text { were sent to you do you } \\
\text { consider that led you to make } \\
\text { the decision to take a course in } \\
\text { the IIC? }\end{array}$} & Message in email & $8.33 \%$ \\
\hline & Phone call & $50 \%$ \\
\hline & $\begin{array}{l}\text { Information provided } \\
\text { on the IIC's office }\end{array}$ & $37,5 \%$ \\
\hline & $\begin{array}{l}\text { Television or radio } \\
\text { advertising }\end{array}$ & $4,16 \%$ \\
\hline \multirow{4}{*}{$\begin{array}{l}\text { Question } 04 \\
\text { Which of the options received } \\
\text { do you consider had more } \\
\text { precise information on } \\
\text { schedules, payment options and } \\
\text { courses offered by IIC? }\end{array}$} & Message in email & $8.33 \%$ \\
\hline & Phone call & $33.33 \%$ \\
\hline & $\begin{array}{l}\text { Information provided } \\
\text { on the premises of } \\
\text { CII }\end{array}$ & $50 \%$ \\
\hline & $\begin{array}{l}\text { Television or radio } \\
\text { advertising }\end{array}$ & $8.33 \%$ \\
\hline
\end{tabular}

TABLE II: ATTRIBUTE MEASUREMENT RESUltS: TIMELY COMMUNICATION

\begin{tabular}{|l|l|l|}
\hline Question & Alternative & Percentage \\
\hline Question 01 & Strongly agree & $33.33 \%$ \\
\cline { 2 - 3 } $\begin{array}{l}\text { The communication by telephone } \\
\text { to inform you about the starting } \\
\text { date of courses and courses opened, } \\
\text { was it done in a timely manner? }\end{array}$ & Agree & $58.33 \%$ \\
\cline { 2 - 3 } & Disagree & $8.33 \%$ \\
\cline { 2 - 3 } & Strongly Disagree & $0 \%$ \\
\hline Question 06 that the & $\begin{array}{l}\text { It has been } \\
\text { adequate }\end{array}$ & $5 \%$ \\
\cline { 2 - 3 } $\begin{array}{l}\text { poriodicity of communication has } \\
\text { been adequate? }\end{array}$ & $\begin{array}{l}\text { It would have } \\
\text { been less }\end{array}$ & $20,83 \%$ \\
\cline { 2 - 3 } & $\begin{array}{l}\text { It would have } \\
\text { been more }\end{array}$ & $20,83 \%$ \\
\hline
\end{tabular}


Regarding the periodicity of communication, 58\% believe that this was adequate while the users who believe that must have been more or less often add up to $21 \%$ in each case.

The results grouped by quality attributes that must meet communication are: significant, timely and continuous are shown in Tables I, II and III.

TABLE III: ATTRIBUTE MEASUREMENT RESUlTS: CONTINUOUS COMMUNICATION

\begin{tabular}{|l|l|l|}
\hline Question & Alternative & Percentage \\
\hline Question 05 & Message in email & $37,5 \%$ \\
\cline { 2 - 3 } $\begin{array}{l}\text { By which medium of } \\
\text { communication would you } \\
\text { like to be informed about } \\
\text { new IIC's services? }\end{array}$ & $\begin{array}{l}\text { Information provided } \\
\text { on the CII's office. }\end{array}$ & $33.33 \%$ \\
\cline { 2 - 3 } & $\begin{array}{l}\text { Television or radio } \\
\text { advertising }\end{array}$ & $12.5 \%$ \\
\hline
\end{tabular}

\section{Financial Assessment}

Net Present Value (NPV): it is a measure of business profitability in absolute net terms. It is done by updating the income and expenses of an investment at a given interest. Finally, it is evaluated if the investment leaves gains.

TABLE IV: CALCULATED NPV

\begin{tabular}{|c|c|}
\hline NPV 2015 & $-1,829.14$ \\
\hline NPV 2016 & $12,196.36$ \\
\hline
\end{tabular}

Both values are positive, but in a comparative way it is the year 2016 that achieves a better performance. The final evaluation between the income and expenditure flows shows that the year 2016 had a Net Present Value much better than 2015

Internal Rate of Return: The Internal Rate of Return or Profitability (IRR), is a method of valuation of investments that measures the profitability of the collections and the updated payments, generated by an investment, in relative terms, that is to say in percentage [19].

TABLE V: INTERNAL RATE OF RETURN

\begin{tabular}{|c|c|}
\hline \multicolumn{2}{|c|}{ TABLE V: INTERNAL RATE OF RETURN } \\
\hline TIR 2015 & $-5 \%$ \\
\hline TIR2016 & $64 \%$ \\
\hline
\end{tabular}

Public organizations must provide services, although many of them are not profitable, is the case of the CII, the internal rate of return in 2015 shows a negative result $-5 \%$, which improves for 2016, with the investment a 64\% positive balance.

\section{CONCLUSIONS}

Public organizations must work and face private organizations to achieve a market share, and not always public organizations can count on resources that private organizations have. Faced with this reality, the proposal was executed so as to implement low-cost digital communications using VoIP technology, even though this technology is not recent, its use is not yet widespread despite the advantages that it entails. The project obtained positive outcomes both from an economic perspective and the communication with the customer. A positive influence on business performance was found. These types of solutions that make use of information and communication technologies play a determining role for the development and promotion of companies that wish to be inserted into digital economies.

\section{REFERENCES}

[1] W. E. F. WEF, The Global Information Technology Report 2016 Slija Baller, Soumitra Dutta, Bruno Lanvin, Geneva, 2016.

[2] R. J. Martelo, I. Blanquicet, and L. Rodriguez, "Metodología para seleccionar aplicaciones de la tecnología de comunicaciones voz sobre la IP para pequeñas y medianas empresas (Pymes). El caso de una agencia de viajes," Información Tecnológica, vol. 26, no. 6, pp. 213-221, 1997.

[3] S. Seo, "VOIP-telephone service: Economic efficiencies and policy implications," Telematics and Informatics, p. 47-55, 2008.

[4] J. Meisel and M. Needles, "Voice over Internet protocol (VOIP) development and public policy implications," The Journal of Policy Regulation and Strategy for Telecommunications, pp. 3-15, 2005.

[5] S. Seo, "VOIP-telephone service: Economic efficiencies and policy implications,” Telematics and Informatics, p. 47-55, 2008.

[6] Statista, (CStatista. (2016). [Online]. 29(12). Available: https://www.statista.com

[7] Sipnology, Sipnology. (May 2017). [Online]. 12. Available: http://www.sipnology.com/en/company/20-voip-growing-statistics

[8] Gestión, Gestión. (Feb. 2016). [Online]. 25. Available: http://gestion.pe/tecnologia/25-lineas-telefonicas-peru-operantecnologia-voip-2155244

[9] H. P. Singh, S. Singh, J. Singh, and S. Khan, "VoIP: State of art for global connectivity - A critical review," Journal of Network and Computer Applications, pp. 365-379, 2013.

[10] I. S. O. ISO, ISO 9001 auditing practices group. (May 2017). [Online]. 12. Available: http://www.inlac.org/documentos/INLAC-0809/Auditando_la_eficacia_de_la_auditoria_interna_rev.1.pdf.

[11] B. Pruitt, Digium. (Sep. 2016). [Online]. 20. Available: http://blogs.digium.com/2012/02/27/why-unified-communicationsinfographic/

[12] M. Jacobs, W. Yu, and R. Chavez, "The effect of internal communication and employee satisfaction on supply chain integration,” Int. J. Production Economics, pp. 60-70, 2016.

[13] I. N. d. E. e. I. INEI, Instituto nacional de estadística e informática. (2014). [Online]. Available: https:/www.inei.gob.pe/estadisticas/indice-tematico/populationaccess-to-internet/

[14] N. Kock, "The psychobiological model: Towards a new theory of computer-mediated communication based on darwinian evolution," Organization Science, pp. 327-348, 2004.

[15] K. Byron, "Carrying too heavy a load? The communication and miscommunication,” Academy of Management, pp. 309-327, 2008.

[16] L. Flores, G. Garcia, and A. Valencia, "Implementación de un sistema de voz sobre IP y call center para la junta de beneficiencia de guayaquil,” Revista Tecnológica ESPOL, 2010.

[17] J. Vergés, Deposit digital de documents de la UAB. (2014). [Online]. Available:

https://ddd.uab.cat/pub/estudis/2014/123138/Eficiencia_comparativa_ Empresa_Publica_vs_Privada_La_evidencia_empirica.pdf

[18] P. F. Garcia, "Intranet y Central VoIP para la Gestión Administrativa de los distritos de Salud de la Dirección Provincial del Carchi," Ecuador, 2014.

[19] J. Iturrioz del Campo, Vergés, Tasa Interna de Retorno o Rentabilidad (TIR). (2013). [Online]. Available: www.academia.edu/download/35252164/PROBLEMA_CON_PERIO DO_DE_GRACIA.docx

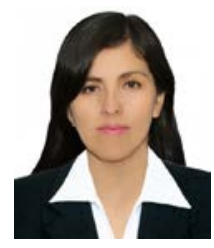

Hesmeralda Rojas Enriquez is a systems and information engineer, software developer at the Universidad Tecnológica de los Andes and professor at the National University Micaela Bastidas de Apurímac. She got the master in business administration and management degree from Alas Peruanas University in 2013.

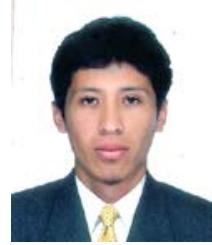

Ronald Alberto Renteria A., is a computer engineer and professor at the Technological University of the Andes. He got the master in business administration and management degree from Alas Peruanas University in 2014. 


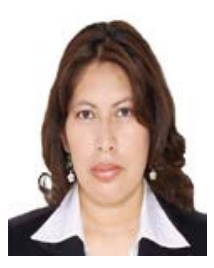

Evelyn Naida Luque Ochoa was born in Was born in Cusco, Peru. She got the master degree in administration at the ESAN University in 2007. She is a computer and systems engineer at the San Antonio Abad University of Cusco in 2003.

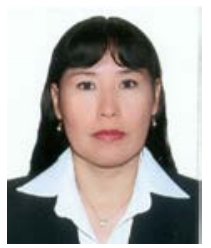

Marleny Peralta Ascue was born in Cusco. She is a systems engineer at the Private University of Tacna. She got the master degree in research, development and information technology, at the San Antonio Abad University of Cusco in 2016.

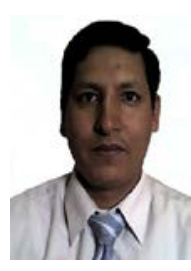

José Luis Merma Aroni was born in Curahuasi. He is a Computer Engineer and Systems in San Antonio Abad University of Cusco. He got the Master degree in sciences mention in Telecommunications from the National University of Engineering in 2013. 